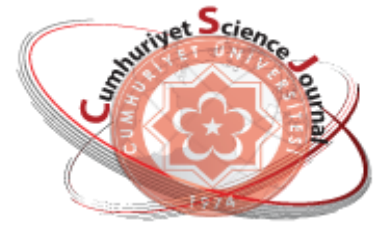

e-ISSN: $2587-246 X$

ISSN: 2587-2680

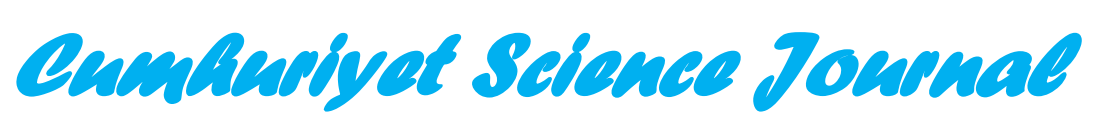

$\cos 7$

Cumhuriyet Sci. J., Vol.39-3(2018) 791-798

\title{
Chitosan Based Edible Films Enriched with Black Cumin Oil for Potential Food Packaging Applications
}

\author{
Duygu ALTIOK \\ Giresun University, Faculty of Engineering, Department of Food Engineering, Giresun, TURKEY \\ Received: 13.07.2018; Accepted: 19.09.2018 \\ http://dx.doi.org/10.17776/csj.443730
}

\begin{abstract}
In this study, chitosan based edible films were prepared by incorporation of black cumin oil. The resultant films were characterized in terms of their surface morphology and mechanical strength. The surface and cross-sectional properties of the films were analyzed by scanning electron microscopy. Essential oil incorporated films had the smooth surface and plate structure at the cross-section. The average thickness of the films was 4-8 $\mu \mathrm{m}$. Adding essential oil increased film opacity. The mechanical properties of films were determined by texture analyzer. Addition of essential oil improved the mechanical property of chitosan film. Antioxidant and antimicrobial activity of black cumin oil were determined to put forward the functional property of resultant films. The trolox equivalent antioxidant capacity of black cumin oil was found as 0.552 $\mu \mathrm{M}$ trolox/g. Black cumin oil showed antimicrobial activity against Escherichia coli, Pseudomonas aeruginosa, Staphylococcus aureus and Staphylococcus epidermidis. Chitosan based films enriched with 1\% black cumin oil revealed both the antioxidant activity and the antimicrobial activity on test microorganisms. Regarding to these results, it has been considered as a functional edible film enriched with essential oil that can protect the food from microbiological deterioration and oxidation.
\end{abstract}

Keywords: Chitosan, Black cumin oil, Edible film, Antioxidant activity, Antimicrobial activity.

\section{Potansiyel Gıda Ambalajı Uygulamaları İçin Çörekotu Yağı ile Zenginleştirilmiş Kitosan Bazlı Yenilebilir Filmler}

\begin{abstract}
Özet. Bu çalışmada çörekotu yağı eklenerek kitosan bazlı yenilebilir filmler hazırlanmıştır. Elde edilen filmler, yüzey morfolojisi ve mekanik mukavemeti açısından karakterize edilmiştir. Filmlerin yüzey ve kesit özellikleri taramalı elektron mikroskobu ile analiz edilmiştir. Uçucu yağ eklenmiş filmlerin yüzeyi pürüzsüz ve kesiti plakalı yapıdadır. Filmlerin ortalama kalınlığı 4-8 $\mu \mathrm{m}$ arasındadır. Uçucu yağ eklemek film opaklığını arttırmıştır. Filmlerin mekanik özellikler tekstür analiziyle belirlenmiştir. Uçucu yağ ilavesi kitosan filmlerin mekanik özelliklerini geliştirmiştir. Elde edilen filmlerin fonksiyonel özelliklerinin ortaya konulması için çörekotu yağının antioksidan ve antimikrobiyal aktivitesi belirlenmiştir. Çörekotu yağının trolox eşdeğer antioksidan kapasitesi $0.552 \mu \mathrm{M}$ trolox/g olarak bulunmuştur. Çörekotu yağı Escherichia coli, Pseudomonas aeruginosa, Staphylococcus aureus ve Staphylococcus epidermidis üzerine antimikrobiyal aktivite göstermiştir. \% 1'lik çörekotu yağı ile zenginleştirilmiş filmler hem antioksidan aktivite hem de test mikroorganizmaları üzerine antimikrobiyal aktivite ortaya koymuştur. Bu sonuçlar göre, uçucu yağ ile zenginleştirilmiş fonksiyonel yenilebilir filmlerin gıdayı mikrobiyal bozulmalardan ve oksidasyondan koruyabileceği düşünülebilir.
\end{abstract}

Anahtar Kelimeler: Kitosan, Çörekotu yağı, Yenilebilir film, Antioksidan aktivite, Antimikrobiyal aktivite. 


\section{INTRODUCTION}

The most important hurdle in food industry is the limited shelf life and loss in quality of foods due to humidity and flavor loss, enzymatic browning, oxidation and microbial spoilage when confronted with food surroundings [1]. An active packaging system has been introduced to extend the shelf life of food and to protect it from such negative environmental factors. The edible films have recently been used to overcome these problems. Edible films applied as a thin layer to the surface or interior of food are obtained from plant and animal sources [2]. The main features of edible films can be considered to be economically and toxicologically safe, reducing moisture losses and browning reactions [3], being biodegradable and edible, exhibiting barrier properties against oxygen and physical stress and having functional properties such as antioxidant and antimicrobial activity [4].

Natural polymers such as alternative plastic proteins, polysaccharides and lipids that are biodegradable, consumable with food and without any environmental concern are suitable for the production of edible films. Chitosan, alginate, carrageenan, starch, cellulose and its derivatives have been used for edible film production. Among these macromolecules, chitosan has been focused for food applications due to its biodegradability, biocompatibility, antimicrobial activity, non-toxic property and film forming capacity [5-6]. Chitosan is produced by the deacetylation of chitin. Chitosan-based films prevent moisture loss, inhibit oxidation, and increase antibacterial activity as well as nutritional value [7].

The most recent and emerging form of antimicrobial packaging is the use of packaging materials and antimicrobial agents to control microbial growth on the food surface. When the antimicrobial agents included in the packaging material, it shows antimicrobial effects on the food contact surface [8]. Natural antimicrobial and antioxidant compounds such as essential oils are preferred while preparing films since they extend the shelf life of product and provides microbial safety for consumers. The antimicrobial, antioxidant and water barrier properties of the films have been improved by incorporating essential oils which are hydrophobic compounds in their natural form [9]. They act to reduce, inhibit, or retard the growth of pathogen microorganisms in packed foods and packaging material. Also, using antioxidant compounds on films breeds some desirable results like discoloration and reducing the rate of particular oxidation reactions by migrating to food. Many studies have been performed on the preparation and characterization of essential oil incorporated films [10]. Yuan et. al. (2015) developed the carvacrol and pomegranate peel extract loaded chitosan based edible films. It was stated that addition of these active agents increased the antioxidant and antimicrobial activity of the films [11]. Suput et. al. (2016) investigated the effect of the incorporation of different essential oil such as black cumin oil and oregano oil to the starch films and the mechanical, thermal and biological film properties. The positive impacts of these essential oils on film properties were stated [12].

Black cumin (Nigella sativa L.) mostly grows in the Middle East and in Western Asian countries. It is good source of nutritionally essential components such as amino acids, carbohydrates, fixed and volatile oils, alkaloids, saponins, and many other compounds [13]. Its volatile oil is usually obtained by cold pressing. The major bioactive compound of black cumin oil is thymoquinone. It constitutes about $30 \%$ of total volatile oil. Thymoquinone is a powerful antioxidant. The other active components are carvacrol, tanethole, and 4-terpineol which have demonstrated significant antioxidant activity [1314].

The main objective of this study was to prepare the chitosan based films enriched with black cumin oil and to determine the characteristics such as morphology and mechanical properties, antioxidant and antimicrobial properties for potential use as active packaging material. 


\section{MATERIALS AND METHODS}

\subsection{Materials}

Low molecular weight chitosan with deacetylation degree of $85 \%$ and black cumin oil were supplied by Aldrich (USA). Acetic acid and ethanol were purchased from Merck (Germany). Trolox (6hydroxy-2,5,7,8,-tetramethylchroman-2carboxylic acid), ABTS (2,2'-azino-bis(3ethylbenzothiazoline-6-sulphonic acid)) and potassium persulfate $\left(\mathrm{K}_{2} \mathrm{~S}_{2} \mathrm{O}_{8}\right)$ from Fluka (Germany) were used for antioxidant analyses. Gentamicin (CTOO24B) was purchased from Oxoid (USA).

\subsection{Film Preparation}

Chitosan was dissolved in $1 \%$ acetic acid solution to prepare $2 \%(\mathrm{w} / \mathrm{v})$ chitosan film forming solution. To obtain the $0.5 \%$ and $1 \%$ essential oil containing film, the black cumin oil was dissolved in ethanol and added by syringe pump (NE 300, USA) to the film forming solution. To obtain homogenous films, the film forming solutions were agitated for $60 \mathrm{~min}$ on a magnetic stirrer. The film forming solution $(20 \mathrm{~g})$ was poured into polystyrene petri dishes and dried in an incubator at $40{ }^{\circ} \mathrm{C}$ for 24 hours. Resultant edible films were peeled off and kept in a desiccator for the analysis.

\subsection{Characterization of Films}

\subsubsection{Film Appearance, Thickness and Surface Morphology}

The color of the edible films was determined by Hunter Lab Colorimeter (MS EZ 4000L, USA). Measurements were expressed as $\mathrm{L}^{*}, \mathrm{a}^{*}$ and $\mathrm{b}^{*}$ which indicate darkness/lightness, greenness (-) / redness (+) and blueness (-) / yellowness (+), respectively. $L^{*}, a^{*}$ and $b^{*}$ values were given as average of five replicate measurements performed on different regions of each film sample. The surface and cross-sectional area morphology of films were analyzed and the film thickness was determined by scanning electron microscope (SEM) (Hitachi SU 1510, USA). Film samples were mounted onto metal grids and coated with gold under vacuum before the analysis. SEM pictures were taken with different magnifications.

\subsubsection{Mechanical Test}

Mechanical properties of edible films such as tensile strength and elongation at break were determined with a Texture Analyzer (TA-XT Plus, USA) according to ASTM D882-83. Films were cut into $(1 \times 5 \mathrm{~cm})$ rectangular strips. The initial grip distance was set to $5 \mathrm{~cm}$ and the film strips were pulled at $5 \mathrm{~mm} / \mathrm{min}$ with a $5 \mathrm{~kg}$ load cell. The tensile strength and elongation data were recorded for minimum five replicates for each sample.

\subsubsection{Antioxidant Activity}

The antioxidant activity of black cumin oil and edible films were determined by ABTS method with slight modifications [10, 15]. Trolox equivalent antioxidant capacity (TEAC) is a measure based on the radical scavenging property of antioxidant-specific components that are included in the film. In this method, the $\mathrm{ABTS}^{+}$ radical was formed by the reaction of $7 \mathrm{mM}$ ABTS and $2.45 \mathrm{M} \mathrm{K} \mathrm{K}_{2} \mathrm{~S}_{2} \mathrm{O}_{8}$. The color of the solution was determined by UV-Visible spectrophotometer (HACH DR6000, USA) at 734 $\mathrm{nm}$. After adjusting the initial absorbance value of $\mathrm{ABTS}^{+}$radical to $0.70 \pm 0.03$ at this wavelength, the sample is added in different concentrations to the $\mathrm{ABTS}^{+}$radical solution. Then the color loss in the $\mathrm{ABTS}^{+}$radical is measured and recorded at every minute during 6 minutes. Results were expressed as TEAC ( $\mu \mathrm{M}$ trolox/g sample).

\subsubsection{Antimicrobial Activity}

The disc diffusion method was used to determine the antimicrobial properties of black cumin oil and films. The standard strains of Escherichia coli and Pseudomonas aeruginosa as gram negative bacteria and Staphylococcus aureus and Staphylococcus epidermidis as gram positive bacteria were used as test microorganisms. The microorganisms kept at $-40{ }^{\circ} \mathrm{C}$ were propagated at $37^{\circ} \mathrm{C}$ in nutrient broth. After $24 \mathrm{~h}$ incubation, the sub-cultures were performed. $6 \mathrm{~h}$ incubated bacterial suspensions were spreaded onto nutrient 
agar surface. The sterile discs were submerged into the black cumin oil and placed onto the inoculated agar plate for $24 \mathrm{~h}$ incubation at $37^{\circ} \mathrm{C}$. In the case of edible films, the film discs with $8 \mathrm{~mm}$ diameter were placed as the same. Gentamicin antibiotic disc was used as positive control. The effectiveness of the samples is determined by the presence of growth inhibition zone appear as clear area underneath or surrounding of the disc.

\section{RESULTS AND DISCUSSION}

\subsection{Film Appearance, Thickness and Surface Morphology}

The edible films and their compositions were given in Table 1. Pure chitosan film (control) was thin, transparent and homogeneous in appearance. When the black cumin oil was incorporated, the transparency of the films reduced and the opacity increased. Both control and essential oil incorporated chitosan films were homogeneous, brilliant and flexible. The color characteristics of the films are presented in Table $1 . \mathrm{L}^{*}, \mathrm{a}^{*}$ and $\mathrm{b}^{*}$ values are the mean values of five parallel measurements.

Table 1. Chitosan based edible films, composition, thickness and color.

\begin{tabular}{|c|c|c|c|c|c|}
\hline \multirow{2}{*}{ Film Code } & \multirow{2}{*}{ Film Composition } & \multirow{2}{*}{ Film Thickness $(\mu \mathrm{m})$} & \multicolumn{3}{|c|}{ Film Color } \\
\hline & & & $\mathbf{L}^{*}$ & $\mathbf{a}^{*}$ & $\mathbf{b}^{*}$ \\
\hline B & $2 \%$ chitosan (control) & 4.21 & 90.52 & -0.11 & 4.05 \\
\hline B1 & $\mathrm{B}+0.5 \%$ black cumin oil & 4.19 & 85.42 & -0.72 & 6.74 \\
\hline $\mathrm{B} 2$ & $\mathrm{~B}+1 \%$ black cumin oil & 7.42 & 84.25 & -0.81 & 7.33 \\
\hline
\end{tabular}

The $L^{*}$ value ( $0=$ black, $100=$ white) is related with the transparency. While it is 90.52 in the control film, it decreased to 84.25 when the black cumin oil was added as $1 \%$ to the film. $\mathrm{L}^{*}$ value proves that the transparency decreased by the addition of essential oil and films became more opaque. This could be drawback when the transparent and colorless food packaging is required. However, opaque coatings may protect food from oxidative deterioration caused by visible and ultraviolet light [16]. $a^{*}$ value was negative for all film samples that indicates the slightly greenish color. Greenish color of the films increased by addition of essential oil compared with the control. $b^{*}$ value was positive for all samples and increased when oil was added. Yellowish color increased by increasing the concentration of the oil in the film.
Surface and cross-sectional morphology and thickness of chitosan-based edible films were visualized by scanning electron microscopy. Images were taken at 100x, 1000x, 2000x, 4000x and 10000x magnifications. SEM images of the films at different magnifications were given in Figure 1. In SEM analysis, the average thicknesses of the films were measured as in the range of 4-8 $\mu \mathrm{m}$. The change in film thickness has been influenced by the amount of black cumin oil in the film. As the amount of black cumin oil increased, the film thickness increased. Chitosan control film (B) has homogeneous, smooth and planar structure that can be explained by the attraction force between chitosan chains, especially at $\mathrm{pH} 5.0$ similar to our previous study result [10]. 

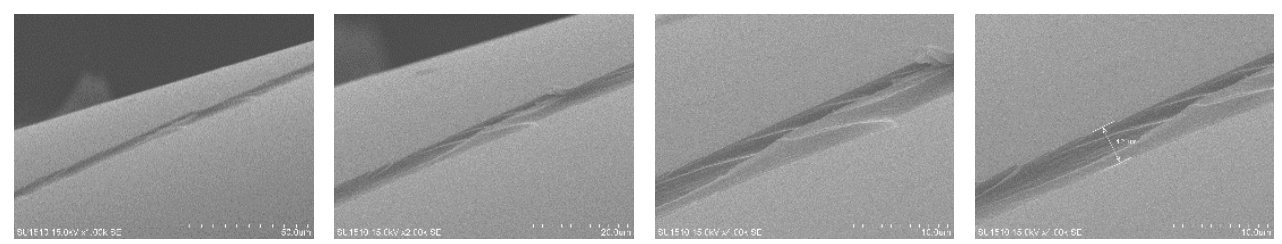

(a)
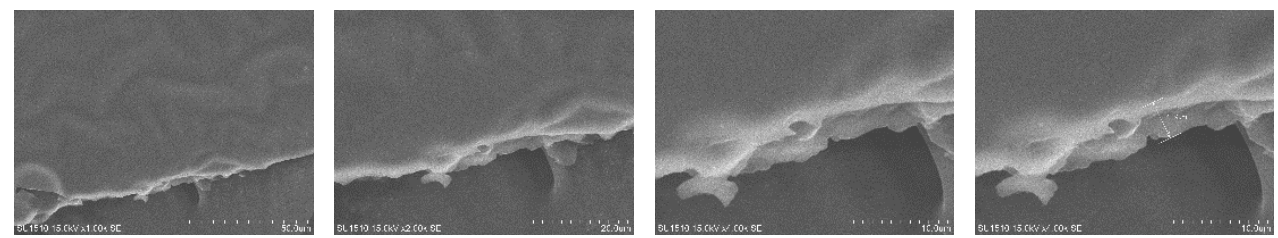

(b)
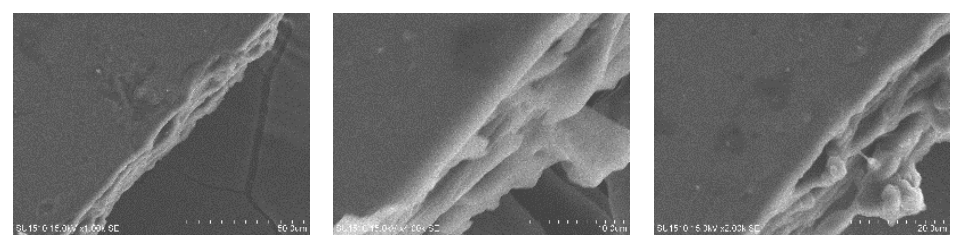

(c)

Figure 1. SEM images taken at different magnifications from surfaces and cross-sections of edible films of a) B ( $2 \%$ chitosan (control)), b) B1 (B+0.5\% black cumin oil), c) B2 (B+1\% black cumin oil).

In addition to this, the oil layer is seen as a separate layer in the films incorporated with black cumin oil. The incorporation of black cumin oil into chitosan film did not significantly affect the planar chitosan structure, but only the distance between the planes increased. These results were compatible with other studies in literature that states the smooth, regular and uniform surface structure is expected for essential oil incorporated films [20].

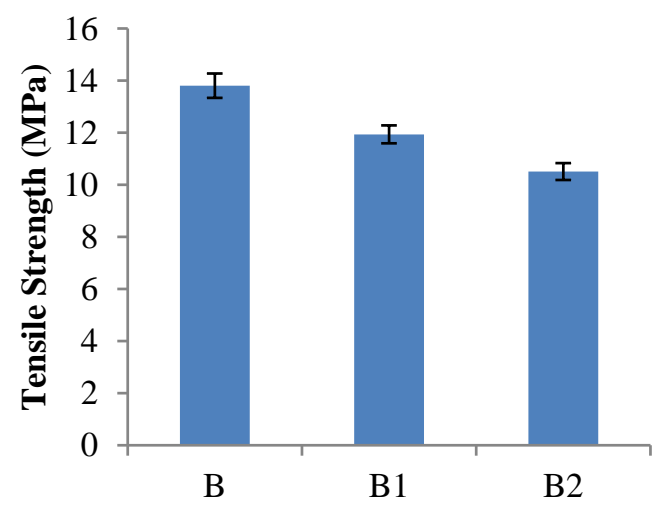

(a)

\subsection{Mechanical Test}

The results of tensile testing are shown in Figure 2a. The tensile strength of the control films was approximately $14 \mathrm{MPa}$ while the incorporation of black cumin oil reduced the tensile strength to 12 $\mathrm{MPa}$ and $10 \mathrm{MPa}$, respectively, for $0.5 \%$ and $1 \%$ oil concentration. This result can be attributed to the plasticizing effect of essential oils [17].

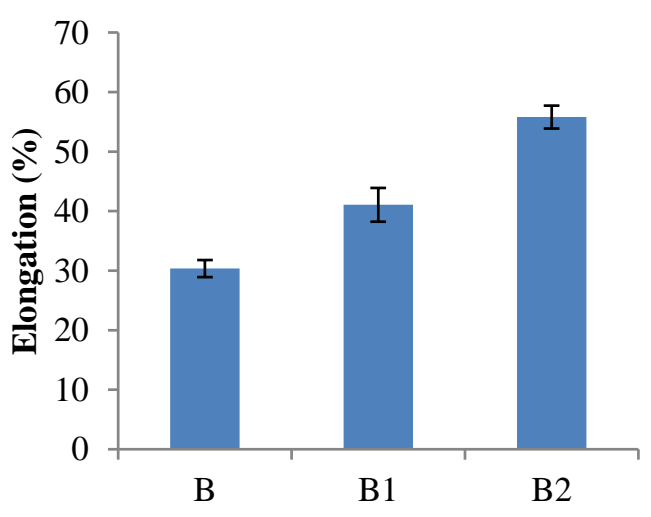

(b)

Figure 2. Tensile test applied to the films (a) Tensile strength of the films; (b) Elongation \% of the films. 
The interaction occurs between the chitosan and essential oil which results the plate structure by decreasing the attraction force between chitosan chains, thereby decreasing the tensile strength. Figure $2 b$ indicates the change in the elongation at break values of tested films. While the elongation at break value of control film was $30 \%$, it increased to $40 \%$ and $55 \%$ by the incorporation of black cumin oil with $0.5 \%$ and $1 \%$ oil concentration in the film, respectively. The changes both in the tensile strength and the elongation at break are in accordance of other findings in literature [18-20]. Incorporation of essential oil to the polymeric matrices improves the mechanical properties of the films by decreasing the tensile strength and increasing the elongation at break values.

\subsection{Antioxidant Activity}

The ABTS discoloration provided the information on the antioxidant activity of both essential oil and essential oil incorporated films. Antioxidant capacity of black cumin oil was determined as $0.552 \mu \mathrm{M}$ of trolox $/ \mathrm{g}$. Compared with the control, the antioxidant activity of the films was significantly increased when black cumin oil was incorporated. Most of the studies reported that mostly phenolic compounds of essential oils result the antioxidant activity [21]. According to studies by Viuda-Martos (2007), the major components of black cumin oil are thymoquinone $(37.6 \%)$, pcymene $(31.2 \%), \quad \alpha$-thujene $(5.6 \%)$ and thymohydroquinone (3.4\%) [22]. Especially thymoquinone has been known with strong antioxidant activity. Gomez-Estaca et. al. (2009) states that the amount of antioxidant substance added to the edible film generally proportional to the degree of antioxidant power of the film [23]. The presence of antioxidant capacity of oils used in edible film is important to prevent the oxidation of food coated with edible film. Films developed with natural antioxidant essential oils with high antioxidant capacity extend the shelf life of food.

\subsection{Antimicrobial Activity}

Disc diffusion assays were applied as two replicates for each sample. All test bacteria exhibited weak resistance to gentamicin antibiotic disc. Antimicrobial activity test indicated that black cumin oil has strong antimicrobial activity against test microorganisms. The antimicrobial activities of control and black cumin oil incorporated chitosan films are shown in Table 2.

Table 2. Disc diffusion zone diameters of edible films and gentamicin against different microorganisms.

\begin{tabular}{|c|c|c|c|c|c|}
\hline \multirow[b]{2}{*}{$\begin{array}{l}\text { Film } \\
\text { Code }\end{array}$} & \multirow[b]{2}{*}{ Film Composition } & \multicolumn{4}{|c|}{ Inhibition zone (mm) } \\
\hline & & $\begin{array}{c}\text { Escherichi } \\
\text { a coli }\end{array}$ & $\begin{array}{l}\text { Pseudomona } \\
\text { s aeruginosa }\end{array}$ & $\begin{array}{c}\text { Staphylococcu } \\
\text { s aureus }\end{array}$ & $\begin{array}{l}\text { Staphylococcus } \\
\text { epidermidis }\end{array}$ \\
\hline $\mathrm{B}$ & $2 \%$ chitosan (control) & 0 & 0 & 0 & 0 \\
\hline B1 & $\mathrm{B}+0.5 \%$ black cumin oil & 0 & 9.5 & 0 & 9 \\
\hline $\mathrm{B} 2$ & $\mathrm{~B}+1 \%$ black cumin oil & 10 & 11 & 9.5 & 9.5 \\
\hline $\mathrm{G}$ & Gentamicin & 14 & 13 & 12 & 11 \\
\hline
\end{tabular}

Here, the inhibition zone shows the diameter of the clear zone around film disc. In all films, the contact surface on agar directly underneath the film discs was clean that indicates the antimicrobial activity. Strong antimicrobial activity was detected for films incorporated with $1 \%$ black cumin oil, as it has antimicrobial activity against Escherichia coli, Pseudomonas aeruginosa, Staphylococcus aureus and
Staphylococcus epidermidis. When the oil concentration is $0.5 \%$, the clear zone was observed only against Pseudomonas aeruginosa and Staphylococcus epidermidis. According to literature, this strong antimicrobial activity is attributed to the thymoquinone which is the major bioactive compound of black cumin oil [13]. As mentioned in other study, the application of essential oil at low concentration in film 
formulation could be useful for many food products by performing antimicrobial activity without altering the natural taste and flavor of the product [20].

\section{CONCLUSION}

Nowadays, the edible films gained important attention due to their positive impacts on food quality and shelf-life. The addition of essential oils to the edible films gives the films extra functionality due to their antioxidant and antimicrobial activity. The present work demonstrated that incorporation of black cumin oil to the chitosan film improved the mechanical properties and brought strong antimicrobial and antioxidant activity to the films. It can be concluded that chitosan films enriched with black cumin oil have great potential to be used as functional food packaging material. These antioxidant and antimicrobial films may enhance the product quality and increase shelf life of food. In future studies, application of these films to various foods and evaluation the effect of these materials on the shelf life of the food would be promising.

\section{Acknowledgement}

This study was financially supported by the Scientific Research Projects Unit of Giresun University with the project code FEN-BAP-A140316-66.

\section{REFERENCES}

[1]. Kella, N.K., Kinsella, J.E. Enhanced thermodynamic stability of b-lactoglobulin at low pH. Biochem. J, 255 (1988) 113-118.

[2]. Kılınççeker O., Hepsağ F. Kaplama Malzemesi Olarak Misır Unlarının Bazı Kalite Özelliklerinin Belirlenmesi. Gida Teknolojileri Elektronik Dergisi, 5 (2) (2010) 20-27.

[3]. Franssen L. R., Krochta J. M. Edible coatings containing natural antimicrobials for processed foods. In: Natural Antimicrobials for The Minimal Processing of Foods, Woodhead Publishing Limited, Abington, (2003) 250-262.

[4]. Cutter C. N. Opportunities for bio-based packaging technologies to improve the quality and safety of fresh and further processed muscle foods. Meat Sci., 74 (2006) 131-142.
[5]. Li, Q., Dunn, E.T., Grandmaison, E.W., Goosen, M.F.A. Applications and properties of chitosan. In: Goosen, M.F.A. (Ed.), Applications of Chitin and Chitosan. Technomic Publishing Co. Inc., Lancaster, PA, (1992) 3-29.

[6]. Tharanathan, R.N., Kittur, F.S. Chitin - the undisputed biomolecule of great potential. Crit Rev Food Sci Nutr 43(1) (2003) 61-87.

[7]. Padua G.W, Wang Q. Formation and properties of corn zein films and coatings. Protein Based Films and Coatings. A Gennadios (Edited), CRC Pres, New York (2002).

[8]. Karagöz, Z., Candoğan, K. Et Teknolojisinde Antimikrobiyal Ambalajlama. Gıda, 32(3) (2007) 113-122.

[9]. Sánchez-González, L. Caracterización y aplicación de recubrimientos antimicrobianos a base de polisacáridos y aceites esenciales. Doctoral Thesis, Universidad Politécnica de Valencia, Spain (2010).

[10].Altiok D., Altiok E., Tihminlioglu F. Physical, antibacterial and antioxidant properties of chitosan films incorporated with thyme oil for potential wound healing applications, J. Mater. Sci. Mater. Med. 21 (2010) 2227-2236

[11].Yuan G., Lv H., Yang B., Chen X., Sun H. Physical Properties, Antioxidant and Antimicrobial Activity of Chitosan Films Containing Carvacrol and Pomegranate Peel Extract, Molecules, 20 (2015) 11034-11045

[12].Šuput D., Lazić V., Pezo L., Markov S., Vaštag Z., Popović L., Radulović A., Ostojić S., Zlatanović S., Popović S. Characterization of Starch Edible Films with Different Essential Oils Addition, Pol. J. Food Nutr. Sci., 66(4) (2016) 277-285

[13].Shabana A., El-Menyar A., Asim M., AlAzzeh H., Al Thani H. Cardiovascular Benefits of Black Cumin (Nigella Sativa), Cardiovasc Toxicol, (2012).

[14].Sultan M.T., Butt M.S., Anjum F.M., Jamıl A., Akhtar S. ve Nasır M. Nutritional Profile of Indigenous Cultivar of Black Cumin Seeds and Antioxidant Potential of Its Fixed and Essential Oil, Pak. J. Bot., 41(3) (2009) 1321-1330.

[15].Altık E., Bayçın D., Bayraktar O., Ülkü S. Isolation of polyphenols from the extracts of olive leaves (Olea europaea L.) by adsorption on silk fibroin, Sep. Purif. Technol., 62 (2008) 342-348 
[16].Rubilar， J.F., Cruz, R.M.S., Silva, H.D., Vicente, A.A., Khmelinskii, I., Vieira, M.C. Physico-mechanical properties of chitosan films with carvacrol and grape seed extract. J. Food Eng. 115 (2013) 466-474.

[17].Pelissari F.M., Grossmann M.V.E., Yamashita F., Pineda E.A.G. Antimicrobial, mechanical, and barrier properties of cassava starch-chitosan films incorporated with oregano essential oil. J. Agric. Food Chem., 57 (2009) 7499-7504.

[18].Benavides S., Villalobos-Carvajal R., Reyes J.E. Physical, mechanical and antibacterial properties of alginate film: effect of the crosslinking degree and oregano essential oil concentration. J. Food Eng., 110 (2012) 232 239.

[19].Ghasemlou M., Aliheidari N., Fahmi R., Shojaee-Aliabadi S., Keshavarz B., Cran M.J., Khaksar R., Physical, mechanical and barrier properties of corn starch films incorporated with plant essential oils. Carbohydr. Polym., 98 (2013) 1117-1126.
[20].Souza A.C., Goto G.E.O., Mainardi J.A., Coelho A.C.V., Tadini C.C. Cassava starch composite films incorporated with cinnamon essential oil: Antimicrobial activity, microstructure, mechanical and barrier properties. LWT - Food Sci. Technol., 54 (2013) 346-352.

[21].Burt S. Essential oils: Their antibacterial properties and potential applications in foods. Int. J. Food Microbiol., 94 (2004) 223-253.

[22].Viuda-Martos M., Ruiz-Navajas Y., Fernandez-Lopez J., Perez-Alvarez J.A., Chemical composition of the essential oils obtained from some spices widely used in Mediterranean region. Acta Chim. Slov., 54 (2007) 921-926.

[23].Gomez-Estaca, J., Gimenez, B., Montero, P., Gomez-Guillen, M.C. Incorporation of antioxidant borage extract into edible films based on sole skin gelatin or a commercial fish gelatin. J. Food Eng. 92 (2009) 78-85. 